\title{
Geneeskundeopleidingen 2005: overstag of bijsturen?
}

Voor u ligt het eerste nummer van een nieuwe jaargang van het Tijdschrift voor Medisch Onderwijs (TMO). Bij de gedaantewisseling van TMO in 2004 is afgesproken dat elk jaar één van de 8 UMC's een foto voor de omslag kiest. In 2004 was dat een foto uit Utrecht, in 2005 zal een foto uit Groningen de omslag sieren. In dit nummer vindt $\mathrm{u}$ een toelichting van Janke Cohen-Schotanus et al. op de keuze van deze foto.

In 2004 is de redactie bewust een andere koers gaan varen. Met meer nadruk dan voorheen wil de redactie dat TMO niet alleen voor onderwijskundigen aantrekkelijk is, maar ook voor docenten met een klinische achtergrond: aantrekkelijk als tijdschrift om te lezen, maar ook aantrekkelijk als tijdschrift om in te publiceren. Ofschoon het ledenaantal van de NVMO (en daarmee automatisch het aantal lezers van TMO) langzaam maar zeker blijft stijgen, wellicht mede door het 'specialistennummer' waar de jaargang 2004 mee begon, is het nog te vroeg om een uitspraak te doen over het effect van die nieuwe koers.

Behalve het format en de inhoud van TMO heeft ook de samenstelling van de redactie in 2004 een aantal wijzigingen ondergaan. Met de komst van Jan van Dalen, Lia Fluit, Paul Stuyt, Benno Bonke en Fedde Scheele is een meer evenwichtige vertegenwoordiging van de verschillende Onderwijs- en Opleidingsregio's ontstaan. Voorts zijn Albert Scherpbier en Cees van der Vleuten bereid gevonden lid te worden van de redactie om daarmee het draagvlak van TMO onder de onderwijs- onderzoekers te vergroten. Helaas heeft Remco Coppoolse, die het hbo-veld binnen de NVMO vertegenwoordigde, de redactie verlaten. Omdat substitutie van zorg en taakherschikking binnen de zorg wezenlijke aspecten zijn van de modernisering van het (para-)medisch onderwijs, zoekt de redactie een opvolger voor hem om de paramedische invalshoek van TMO te kunnen blijven garanderen.

Dit jaar kunt $\mathrm{u}$ van ons een tweetal nieuwe rubrieken verwachten, namelijk Nederlands onderzoek in buitenlandse tijdschriften en Proefschriften. Voor de eerste rubriek is Jan van Dalen verantwoordelijk, voor de tweede rubriek Lia Fluit. Verder dienen we dit jaar een aanvraag in bij de National Library of Medicine (NLM) in de Verenigde Staten voor opname van TMO in de Index Medicus. De wijzigingen die TMO vorig jaar heeft ondergaan (zoals het colofon, de gestandaardiseerde beoordelingsprocedure van manuscripten en de gestandaardiseerde Engelse vertaling) zijn voorbereidingen geweest op deze aanvraag. Wij hopen dat het opnemen van TMO in de Index Medicus (en daarmee in de citation index van de NLM) de belangstelling van auteurs om in TMO te publiceren verder zal vergroten.

Tot zover een overzicht van wat er bij TMO is veranderd of gaat veranderen. Maar welke veranderingen zullen zich binnen het medisch onderwijs de komende tijd voordoen? Krijgen we te maken met wezenlijke koerswijziging ('overstag') of is er slechts sprake van voorzichtig bijsturen? Voor de beantwoording van de- 
ze vraag wil ik kort stil staan bij enkele aspecten van de onderwijsvernieuwingen van de initiële en medisch specialistische vervolgopleidingen. Ik realiseer mij dat vergelijkbare veranderingen zich ook bij vele paramedische opleidingen (hbo en wo) voordoen. Zonder die opleidingen te kort te willen doen, laat ik deze echter in de context van dit redactioneel buiten beschouwing.

Het proces van modernisering, ingezet door onder meer de rapporten De arts van straks $^{1}$ en De zorg van morgen, ${ }^{2}$ is door de Stuurgroep Modernisering Opleidingen en Beroepsuitoefening in de Gezondheidszorg (MOBG) stevig ter hand genomen. Binnen 5 jaar moet deze stuurgroep, ingesteld door de minister van VWS, een nieuwe structuur van een samenhangend stelsel van beroepen en opleidingen in de zorg opzetten.

Inmiddels zijn binnen de initiële opleiding de eerste stappen gezet om het programma van de geneeskundeopleiding een bachelor-masterstructuur te geven. Vijf van de acht UMC's (VUmc Amsterdam, Groningen, Maastricht, Nijmegen en Utrecht) maken gebruik van de mogelijkheid om op basis van het recente visitatierapport een vervroegde aanvraag voor de accreditatie van een bachelor- en masterprogramma van de opleiding te doen. In dat verband hebben die vijf UMC's gezamenlijk, maar met behoud van ieders eigen curriculumkenmerken, eindtermen van de bacheloropleiding geformuleerd. Voor de inrichting van de masteropleiding blijft het Raamplan 2001 Artsopleiding richtinggevend. ${ }^{3}$ Tot op zekere hoogte zullen er verschillen tussen de UMC's blijven bestaan bij de uitwerking van de eindtermen van de bachelorprogramma's. Dat maakt dat doorstroom van het ene naar het andere UMC na het bachelordiploma slechts mogelijk is met een aanvullend programma. Het ligt voor de hand dat een student met een bachelordiploma automatisch kan instromen in het masterprogramma van hetzelfde UMC. Voor studenten die in hun bachelorfase ervaren toch geen medische loopbaan te ambiëren, biedt de bachelormasterstructuur de mogelijkheid om een andere masteropleiding te volgen dan de geneeskundemaster. Hiermee draagt de bachelor-masterstructuur bij aan een meer flexibel opleidingenstelsel. Vanuit de invalshoek om aan de behoefte aan professionals op het gebied van technologie en zorg te kunnen voldoen, pleiten in dit nummer van TMO Sminia et al. ook voor betere doorstroommogelijkheden tussen medische en andere opleidingen. ${ }^{4}$

Maar ook de medisch specialistische vervolgopleidingen ervaren de noodzaak tot modernisering. Al eerder is in dit tijdschrift aandacht besteed aan de besluitvorming daarover door het Centraal College Medische Specialismen (CCMS). ${ }^{5}$ Betere aansluiting op de verworven kennis en vaardigheden in de initiële opleiding, gebruik maken van het schakeljaar, het toepassen van nieuwe onderwijskundige instrumenten (zoals het portfolio, Korte Klinisch Beoordelingen en de periodieke kennistoets) zijn elementen van de door het CCMS voorgestane onderwijsvernieuwing. De eerste ervaringen in Utrecht met het schakeljaar, waarbij de zesdejaars student als semi-arts functioneert, zijn zeer positief [persoonlijke waarneming]. Het schakeljaar heeft tot doel dat de student zich volgens het concept van competentieleren verder kan ontwikkelen en verdiepen in een eigen gekozen vakgebied. De student functioneert in de semi-artsstage als beginnende aios (arts in opleiding tot specialist), maar dan zonder de formele bevoegdheid (de semiarts is bekwaam, maar nog niet bevoegd). De uitdaging zal zijn om de opleiders van de vervolgopleidingen goed inzicht te ge- 
ven in de competenties die de 'nieuwe stijl' basisarts heeft bij de aanvang van de vervolgopleiding, zodat zij weten wat zij mogen verwachten van een beginnende aios (is deze net zo goed als een beginnende aios die een 'ouderwets' curriculum heeft gevolgd?). Hiervoor is het belangrijk om middels onderzoek de kwaliteit van de 'nieuwe stijl' basisarts vast te leggen. Daarnaast zal het voor een optimaal rendement van het schakeljaar nodig zijn om in nauw overleg met de KNMG-colleges, de Stuurgroep MOBG en wellicht ook andere gremia uitstroomprofielen van het schakeljaar te definiëren die aansluiten bij de kenmerken van de verschillende vervolgopleidingen: (verpleeg-)huisartsgeneeskunde, sociale geneeskunde en de 'beschouwende', 'snijdende' of 'ondersteunende' medische specialismen. Slechts op deze manier kunnen de in het schakeljaar verworven kennis en vaardigheden daadwerkelijk worden benut in de vervolgopleiding.

De op gang gebrachte onderwijsvernieuwing is geen voorzichtig bijsturen, maar betekent een wezenlijke verandering van de koers. Voor de initiële opleidingen is die koersverandering ingezet met de curriculumherzieningen in de UMC's. De vervolgopleidingen moeten nu volgen. $\mathrm{Er}$ zijn inmiddels diverse initiatieven op landelijk en regionaal niveau gaande. Een goede aansturing en coördinatie daarvan zal onontbeerlijk zijn voor het succesvol wijzigen van de koers. Een uitdaging voor niet alleen de Stuurgroep MOBG, maar voor iedereen die het medisch onderwijs een warm hart toedraagt.

\section{Jan Borleffs}

\section{Literatuur}

1. Meyboom-de Jong B, Schmit Jongbloed LJ, Willemsen MC, editors. De arts van straks - een nieuw medisch opleidingscontinuüm. Utrecht: KNMG/DMW-VSNU/VAZ/NVZ/LCVV; oktober 2002.

2. LeGrand-van den Bogaard MJM, Rooijen APN, editors. De zorg van morgen - flexibiliteit en samenhang. Rapport van de Commissie Implementatie Opleidingscontinuüm en Taakherschikking. Den Haag: Ministerie van VWS; juli 2003.

3. Metz JCM, Verbeek-Weel AMM, Huisjes HJ. Raamplan 2001 Artsopleiding - bijgestelde eindtermen van de artsopleiding. Nijmegen: Mediagroep; 2001.

4. Sminia T, Sanders FBM, Weerd AW de, Wieringa PA, Duchatteau DC, Schmit Jongbloed LJ, et al. Techniek met zorg: kwantiteit en kwaliteit van zorgtechnologische opleidingen. Tijdschrift voor Medisch Onderwijs 2005;24(1):35-43.

5. Bleker OP, Cate ThJ ten, Holdrinet RSG. De algemene competenties van de medisch specialist in de toekomst. Tijdschrift voor Medisch Onderwijs 2004;23(1):4-14. 